\title{
First shots fired in biological warfare
}

Sir - Redmond et al. have described in Scientific Correspondence ${ }^{1}$ new evidence for a covert German attempt to attack Norwegian reindeer with biological weapons to interfere with their use as draught animals to ferry British supplies across northern Norway to Russia during the First World War. These events were not an isolated incident but were part of an ambitious programme of biological warfare directed against animals in neutral trading partners of the Allied forces from 1915 to 1918.

Secret agents were sent to at least five countries (Romania, Spain, Norway, the United States and Argentina) with microbial cultures and instructions to infect shipments to the Allies of horses, mules, cattle and sheep. The bacteria used were those that cause anthrax and glanders ${ }^{2-4}$.

Germany's programme of biological sabotage began in 1915, with a series of attacks on animals on the eastern seaboard of the United States (neutral until 1917), whence were shipped large amounts of material, including horses and mules, to the Allies. The central player in the US biological sabotage programme, and possibly its architect, was Anton Dilger, an American raised in Germany and trained as a physician there. He returned to the United States in early 1915 and set up a basement laboratory in Washington DC, where he grew cultures of anthrax and glanders. The microbes were suspended in liquid in test-tubes, and a crew of longshoremen recruited by the Germans wandered among the stockades where animals were collected for trans-shipment, jabbing them with needles dipped into the microbial cultures. This went on for about a year, until a few months after Dilger returned to Germany early in 1916.

In mid-1915, Captain Rudolf Nadolny of the general staff's Berlin headquarters (probably Dilger's boss) shipped anthrax and glanders cultures to the German embassy in Bucharest for Bulgarian agents collaborating with the Germans, targeting the Romanian animal trade with Russia. The programme came to a halt in August 1916, when Romania broke its neutrality and declared war on Austria-Hungary. After the Central Powers' diplomats were expelled, the Romanian police searched the grounds of the German legation,

discovering anthrax and glanders cultures. No-one at the time suspected that it was evidence not merely of intent to commit biological warfare, but rather of a continuing operation.

Biological sabotage began in neutral Spain a bit later, although the details are much less well documented. It appears that Spanish horses to be shipped to France were the main targets, although other targets in the French Pyrenees and in Portugal were probably also involved. The Spanish programme, and its offspring in Argentina, shared with the Norwegian programme the use of ampoules of bacteria concealed in sugar cubes to be fed to intended victims.

Spain was the staging point for shipment of cultures and agents to neutral Argentina, a major supplier of cattle, horses and mules to the Allies. A German secret agent, Herman Wuppermann, travelled by U-boat (probably carrying cultures) from Croatia to neutral Spain, then by commercial steamship to Argentina. He apparently did not establish his own culture lab in Buenos Aires, and was dependent on replenishment with microbes in sugar cubes from Berlin.

The Argentinian programme appears to have ended in 1918, a victim of the increasing difficulty of international transport of microbes and agents. So ended the first modern use of microbes as weapons, and the only documented instance of deliberate attack on neutral countries with microbial agents. Its effect has yet to be adequately evaluated.

\section{Mark Wheelis}

Section of Microbiology, University of California, 1 Shields Avenue, Davis, California 95616, USA

1. Redmond, C. et al. Nature 393, 747-748 (1998).

2. Wheelis, M. in Biological Warfare From the Middle Ages to 1945 (eds Geissler, E. \& Moon, J. E. v. C.) (Oxford Univ. Press, New York, in the press).

3. Geissler, E. Militargeschichtliche Mitteilungen 56, 107-155 (1997).

4. Geissler, E. Biologische Waffen - nicht in Hitlers Arsenalen: Biologische und Toxinkampfmittel in Deutschland 1915-1945 (LIT, Munster, 1998).

\section{HowDiana climbed the ratings at the zoo}

Sir - "That which we call a rose by any other name would smell as sweet", but it seems that our perceptions of animals are affected by their names in interesting ways.

Visitors to London Zoo were asked to rank eight photographs of animals in the order that they would choose to help their conservation. The study included 57 taxa and was designed so that, after 57 respondents, each picture had been displayed with every other exactly once, and had appeared once in each position on the display. The design was repeated, with different visitors, but with common names added as captions to the pictures.

The two sets of rankings showed good agreement in general $(r>0.8)$, with the 'named' and 'unnamed' ranks of most species being within six places. In common with other surveys, we found that big cats were extremely popular choices: the Sumatran tiger and Persian leopard topped both charts, with the Asiatic lion always in

\begin{tabular}{|c|c|c|c|c|c|}
\hline \multicolumn{3}{|l|}{ Highest climbers } & \multicolumn{3}{|l|}{ Biggest fallers } \\
\hline Species & $\begin{array}{c}\text { Rank without } \\
\text { names }\end{array}$ & $\begin{array}{c}\text { Rank with } \\
\text { names }\end{array}$ & Species & $\begin{array}{c}\text { Rank without } \\
\text { names }\end{array}$ & $\begin{array}{l}\text { Rank with } \\
\text { names }\end{array}$ \\
\hline Diana monkey & $18=$ & $6=$ & Fennec fox & 7 & $21=$ \\
\hline $\begin{array}{l}\text { Rothschild's mynah/Bali } \\
\text { starling }\end{array}$ & $28=$ & $8=$ & $\begin{array}{l}\text { Red-faced black spider } \\
\text { monkey }\end{array}$ & $10=$ & $26=$ \\
\hline Royal python & 48 & $24=$ & Strawberry poison frog & $23=$ & $39=$ \\
\hline British wartbiter cricket & $53=$ & $26=$ & Southern tomato frog & 32 & 45 \\
\hline Red-bellied piranha & 49 & $30=$ & Hyacinth macaw & $21=$ & 46 \\
\hline \multirow[t]{3}{*}{ Pallid gerbil } & 43 & $30=$ & Rodrigues fruit bat & $36=$ & 50 \\
\hline & & & Green imperial pigeon & 34 & $51=$ \\
\hline & & & $\begin{array}{l}\text { Red-back black widow } \\
\text { spider }\end{array}$ & 35 & 56 \\
\hline
\end{tabular}

the top five. Polynesian tree snails were a fixture in last place.

In contrast, the name had a marked effect on the positions of several species (Table 1). Names including words with obvious negative connotations (such as poison, spider, bat) seemed to affect species' rankings adversely. Inspection of species whose rankings moved the other way suggests unexpected insights into the national psyche - the highest climber was also the only species whose name indicated it to be British. And the Diana monkey rose by 12 places into the top ten when named. Interestingly, this climb is only half that managed by the royal python - and indeed only on a par with the performance of the pallid gerbil.

\section{Claire Carvell}

143 Bouverie Avenue South, Salisbury SP2 8EB, UK Nicholas F. J. Inglis

Dept of Mathematics, Sultan Qaboos University, PO Box 36, Al-Khod, Post Code 123, Sultanate of Oman Georgina M. Mace

Institute of Zoology, Zoological Society of London, Regent's Park, London NW1 4RY, UK

Andy Purvis

Department of Biology, Imperial College,

Silwood Park, Ascot SL5 7PY, UK 